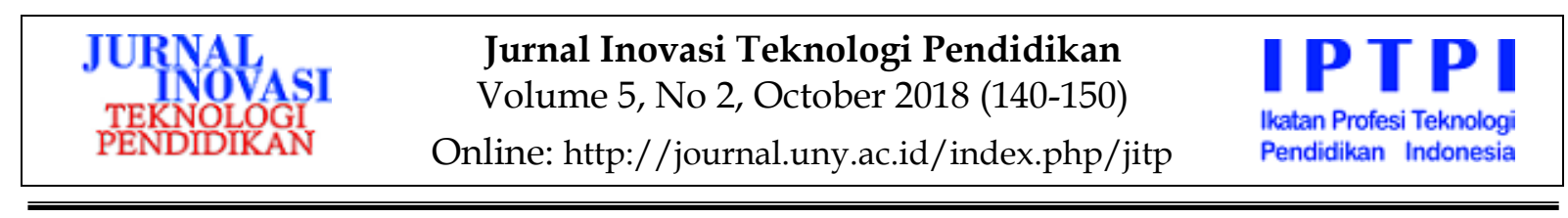

\title{
AUDIOBOOK PEMBELAJARAN MATA KULIAH LITERATUR BERDASARKAN PERSPEKTIF BEHAVIORAL UNTUK MENINGKATKAN PEMAHAMAN BAHASA JERMAN
}

\author{
Barbara Desriana ${ }^{*}$, C. Asri. Budiningsih 1 \\ 1 Universitas Negeri Yogyakarta \\ 1Jl. Colombo No. 1, Depok, Sleman 55281, Yogyakarta, Indonesia \\ * Corresponding Author. Email: desrianabarbara@gmail.com
}

\begin{abstract}
Abstrak
Tujuan penelitian ini adalah untuk: menghasilkan audiobook pada mata kuliah Literatur, mendapatkan kelayakan audiobook yang dihasilkan pada mata kuliah Literatur, dan mengetahui keefektifan media audiobook terhadap hasil belajar mahasiswa prodi pendidikan bahasa Jerman semester 5 di Universitas Negeri Yogyakarta. Metode penelitian yang dikembangkan pada produk ini adalah Penelitian dan Pengembangan (R\&D) dengan menggunakan pendekatan Borg and Gall yang meliputi penelitian dan pengumpulan data, perencanaan, pengembangan desain produk, uji coba lapangan awal, revisi produk, uji lapangan utama, revisi uji coba lapangan, uji lapangan, revisi akhir dan desiminasi dan implementasi. Hasil penelitian ini menunjukkan bahwa produk media audiobook pembelajaran Literatur yang dihasilkan adalah layak dan efektif digunakan sebagai media suplemen dalam kegiatan pembelajaran. Kelayakan produk ini didukung berdasarkan penilaian dari ahli materi dengan perolehan rata-rata sebesar 4,38 dan ahli media dengan rata-rata sebesar 3,8. Keefektifan penggunaan media suplemen audiobook dibuktikan dengan peningkatan hasil belajar mahasiswa dari rata-rata 52,87 menjadi 74,48.
\end{abstract}

Kata kunci: Media Audiobook, behavioral, bahasa Jerman

\section{LITERATURE LEARNING AUDIOBOOK BASED ON BEHAVORIAL PERSPECTIVE TO ELEVATE GERMAN LANGUAGE UNDERSTANDING}

\begin{abstract}
The objectives of this researh are to: create Literature Audiobook, get the appropriateness of Literature Audiobook, and the effectiveness of Audiobook to the result of students of German Diploma Programme in State University of Yogyakarta. The Research method that was used in this product is Research and Development (RED) with Borg and Gall approach that consists of research information collecting, planning, developing preliminary form of product, preliminary field testing, main product revision, main field testing, operational product revision, operational field testing, final product revision, and dissemination and implementation. The results of the research showed that Audiobook Literature learning product is worthy and effective to be used as supplement of learning media. The worthiness of this product supported by assessment result is conducted by matter expert(s) indicate a score that is approximately 4.38 and media expert(s) to product quality with score indicate approximately 3.8. The effectiveness of audiobook media supplement is proven by the increase of student's score from approximately 52.87 to become 74.48 .
\end{abstract}

Keywords: Audiobook media, behavioral, German

Permalink/DOI: http://dx.doi.org/10.21831/jitp.v5i2.13377 


\section{Pendahuluan}

Penguasaan bahasa Asing dewasa ini merupakan salah satu kebutuhan urgensi yang harus dimiliki oleh setiap individu sebagai sarana berkomunikasi. Edwin Newman (Abdulhak \& Darmawan, 2013, p. 23) menjelaskan bahwa komunikasi merupakan suatu proses untuk mengubah sejumlah orang menjadi sekelompok orang yang berfungsi. Adler (2006, p. 6) menambahkan bahwa komunikasi merupakan simbol yang digunakan untuk merepresentatifkan proses, ide maupun kejadian-kejadian dengan cara memungkinkan terjadinya komunikasi. Proses komunikasi berjalan dengan baik, apabila bahasa yang digunakan dapat dipahami oleh yang lainnya.

Pada hakikatnya, kegiatan berkomunikasi merupakan sebuah proses untuk memproduksi dan memahami ujaran maupun ungkapan. Bahasa menurut Anas \& Mohmammad (2015, p. 11) merupakan suatu sistem simbol lisan yang arbitrer yang dipakai oleh sekelompok masyarakat untuk dapat berkomunikasi dan berinteraksi dengan sesamanya berdasarkan pada budaya yang telah disepakati bersama. Heshi \& Nasrabadi (2016, p. 10) menambahkan, bahwa bahasa merupakan refleksi dari moralitas dan kreativitas seseorang dan alat untuk dapat berinteraksi dengan lingkungan dan sesama rekan-rekan. Bahasa inilah kemudian dapat memengaruhi pola pikir seseorang untuk dapat memahami setiap pesan atau informasi yang disampaikan baik secara tertulis maupun oral. Hal tersebut tentunya dapat diperoleh melalui pembelajaran formal dan informal. Dalam hal ini, bahasa dapat dipelajari melalui penanaman pemahaman konsep bahasa yang benar melalui materi ajar yang telah dirancang.

Seyhan (2011, p. 54) mengatakan, bahwa berbicara mengenai bahasa asing berarti mengetahui dan mengerti budaya asing tersebut di luar pemahaman bahasa yang ingin dipelajari seperti struktur dan penulisan kalimat, karena bahasa tidak dapat dipisahkan dari budaya. Bahasa Jerman merupakan salah satu pelajaran bahasa Asing yang dijadikan sebagai program studi bahasa Jerman di beberapa universitas yang ada di Indonesia untuk membekali mahasiswa nantinya berkarya dengan bahasa tersebut. Struktur bidang studi bahasa Jerman mengacu kepada hubungan-hubungan di antara bagian bidang studi itu sendiri. Bahasa Jerman memiliki karakteristik khusus dibandingkan dengan bahasa Asing lainnya. Schlücker (2012) mengatakan bahwa bahasa Jerman dapat dijelaskan dari perspektif komparatif sebagai suatu komposisi bahasa. Dengan kata lain, komposisi adalah pola yang sangat produktif untuk pembentukan kata dalam bahasa Jerman seperti komposisi nominal dan kata sifat.

Bailey \& Nunan (1996, p. 155) menambahkan ketika mahasiswa yang ingin belajar bahasa, harus mengetahui konsep bahwa belajar tidak hanya sebagai sebuah proses yang diperoleh berdasarkan aturan secara linguistik atau berpartisipasi dalam kegiatan komunikasi, tetapi belajar bahasa juga merupakan suatu proses di mana mahasiswa terus-menerus menempatkan diri untuk memposisikan konsep pemikirannya masing-masing.

Menurut Korkmaz (2013, p. 100) dalam penelitiannya, bahwa ketika ingin belajar bahasa asing, pemahaman yang lebih baik dari tingkat penggunaan strategi belajar adalah sangat penting bahwa mahasiswa harus paham strategi mereka sendiri untuk mendapatkan manfaat yang baik dari proses belajar. Berikut dijelaskan oleh Pachler, Evans, Redondo, \& Fisher (2014, p. 62) tentang penelitian yang telah dilakukan oleh Chamot, bahwa penggunaan strategi belajar dengan sistem pengulangan dalam pelajaran bahasa sangatlah penting. Pertama, memungkinkan mahasiswa terlibat langsung untuk mendapatkan wawasan ke dalam meta kognitif, proses sosial dan afektif. Kedua, Belajar dengan menggunakan strategi pembelajaran dapat membantu mahasiswa menjadi lebih baik untuk pembelajaran bahasa. 
Pateda (2015, p. 49) menjelaskan bahwa bahasa pada dasarnya bukan merupakan suatu ciri alamiah yang terpisah, melainkan salah satu kemampuan yang berasal dari kematangan kognitif. Pateda juga menambahkan bahwa bahasa disusun oleh nalar, oleh sebab itu perkembangan bahasa juga harus berlandas pada perubahan yang lebih mendasar yang terdapat dalam kognisi seseorang. Kemampuan ini didasarkan pada kemampuan awal yang digunakan untuk mempermudah proses penyandian, penyimpanan, dan pengungkapan informasi yang baru diterima. Degeng (2013, p. 72) mengklasifikasikan perilaku atau kemampuan awal mahasiswa menjadi tiga jenis yang meliputi kemampuan awal siap pakai, kemampuan awal siap ulang, dan kemampuan awal pengenalan.

Proses pembelajaran dapat berlangsung dengan baik, apabila dosen mengetahui karakteristik dan perilaku awal mahasiswa (entering behavior) berupa pengetahuan, keterampilan, dan sikap awal saat memulai pembelajaran. Suparman $(2012$, p. 39) menjelaskan bahwa perilaku dan karakteristik awal mahasiswa harus relevan dengan proses pembelajaran yang dilaksanakan yang berupa latar belakang pendidikan, motivasi belajar yang mempengaruhi proses pembelajaran dan hasil belajar mahasiswa, akses sumber belajar yang mempermudah mahasiswa untuk belajar kapan dan di mana pun, kebiasaan belajar mahasiswa seperti apakah mahasiswa terbiasa dengan pembelajaran tatap muka atau lebih senang dengan pembelajaran mandiri, domisili tempat tinggal, disiplin waktu belajar yang akan mempercepat penyelesaian tugas-tugas, dan kebiasaan belajar secara sistemastik. Perilaku awal mahasiswa ini nantinya digunakan untuk mendesain pembelajaran bahasa Jerman dalam mata kuliah Literatur yang tentunya berlandaskan pada prinsipprinsip desain pembelajaran.

Berdasarkan penjelasan di atas dapat disimpulkan, bahwa untuk menghasilkan pembelajaran yang optimal sangat penting diketahui kemampuan, pengetahuan dan keterampilan awal mahasiswa. Hal tersebut diperlukan agar dosen dapat mendesain pembelajaran dan memilih strategi dan media yang tepat sesuai dengan karakteristik mahasiswa. Berdasarkan hasil analisis mahasiswa semester 5 kelas B di Universitas Negeri Yogyakarta disimpulkan bahwa kemampuan berbahasa yang telah dipelajari selama 4 semester dianggap kurang membekali mahasiswa untuk memahami teks bahasa Jerman seperti kemampuan mendengarkan yang lemah maupun kemampuan berbicara yang tidak luwes. Sebagai tambahan, diperoleh hasil angket yang juga mendeskripsikan, bahwa kurang lebih $24 \%$ mahasiswa dari mahasiswa semester 5 kelas B tersebut memiliki motivasi untuk mempelajari materi yang dipelajari dan mengulang kembali materi. Sedangkan metode belajar secara mandiri dan tatap muka merupakan sistem pembelajaran yang diminati oleh mahasiswa.

Pelaksanaan pembelajaran bahasa Jerman ternyata tidak selalu berjalan sesuai dengan yang diharapkan. Ada beberapa kendala dan permasalahan belajar yang dapat menghambat kegiatan ini yang tentunya berpengaruh terhadap hasil belajar mahasiswa. Berdasarkan hasil wawancara pada salah seorang dosen program studi pendidikan bahasa Jerman Universitas Negeri Medan, terdapat banyak kendala yang berasal dari mahasiswa itu sendiri yang mengakibatkan kurangnya pemahaman mahasiswa terhadap teks wacana bahasa Jerman baik secara tulis maupun lisan. Kendalakendala yang dimaksud meliputi kekuatiran disertai perspektif mahasiswa terhadap prospek masa depan bahasa Jerman yang memiliki peluang kerja yang rendah. Hal tersebut tentunya dapat mempengaruhi minat belajar mahasiswa. Minat yang rendah sangat mempengaruhi kinerja belajar mahasiswa dan bahkan hasil belajarnya.

Wawancara lainnya juga dilakukan kepada salah seorang dosen program studi bahasa Jerman di Universitas Negeri Yogyakarta. Dari hasil wawancara diperoleh keterangan, bahwa dalam kegiatan belajar mengajar mahasiswa bahasa Jerman di Univeritas Negeri Yogyakarta seakan-akan 
fokus mendengarkan materi yang disampaikan oleh dosen, tetapi tidak semua mahasiswa mampu menyimak dan merespon materi tersebut. Sebagai akibatnya, kebanyakan mahasiswa menjadi nyaman dan terlena oleh ketidakpahaman tersebut karena kurangnya pemberian stimulus untuk merespon materi.

Wawancara lainnya juga dilakukan kepada salah seorang dosen program studi bahasa Jerman di Universitas Negeri Yogyakarta. Dari hasil wawancara diperoleh keterangan, bahwa dalam kegiatan belajar mengajar mahasiswa bahasa Jerman di Univeritas Negeri Yogyakarta seakan-akan fokus mendengarkan materi yang disampaikan oleh dosen, tetapi tidak semua mahasiswa mampu menyimak dan merespon materi tersebut.

Perolehan keterangan lainnya terkait permasalahan pembelajaran didapatkan melalui pemberian angket analisis kebutuhan dan karakteristik mahasiswa. Berdasarkan angket yang diberikan, diperoleh informasi bahwa mahasiswa mengalami kesulitan untuk memahami isi gagasan dari wacana yang dibaca. Hal tersebut disebabkan oleh minimnya penguasaan kosakata. Kurangnya kosakata yang dimiliki tentunya mempengaruhi mahasiswa untuk mengembangkan bahasa Jerman melalui komunikasi sehari-hari. Menyikapi permasalahan tersebut, banyak metode dan strategi bervariasi digunakan oleh dosen untuk meningkatkan minat mahasiswa terhadap empat kemampuan bahasa Jerman yang meliputi kemampuan mendengar (hören), membaca (lesen), menulis (schreiben) dan berbicara (sprechen). Adapun metode yang digunakan saat proses belajar mengajar berlangsung adalah role playing, metode diskusi, metode example non example, dan sebagainya. Hanya saja, penggunaan metode maupun media menjadi efektif jika digunakan sesuai dengan karakteristik materi dan mahasiswa.

Selain kendala-kendala, ada juga potensi-potensi yang ditemukan sebagai hal positif untuk memecahkan masalah pembelajaran. Adapun potensi-potensi tersebut meliputi pemberian stimulus berupa konsep, prinsip dan pengalaman baru. Terjadinya perubahan tersebut didasari oleh adanya rangsangan (stimulus) baik dari sisi eksternal maupun internal mahasiswa yang nantinya menimbulkan respon. Budiningsih $(2012$, p. 20) menekankan bahwa belajar menurut kaum behavioristik adalah perubahan tingkah laku yang terjadi akibat adanya interaksi antara stimulus dan respon. Adapun prinsip-prinsip stimulus respon yang dikemukakan oleh Knowles (1990, p. 67) adalah sebagai berikut mahasiswa harus aktif, bukan hanya sebagai pendengar yang pasif, frekuensi pengulangan masih sangat penting untuk memperoleh keterampilan, penguatan adalah penting, generalisasi dan diskriminasi penting, dan dorongan sangat penting dalam belajar

Potensi lainnya adalah bahwa mahasiswa gemar mendengarkan musik ditambah dengan setiap mahasiswa memiliki alat untuk memutar musik atau audio seperti handphone. Melalui potensi ini, maka timbullah ide untuk mengembangkan sebuah media suplemen pembelajaran berupa audiobook yang dapat digunakan untuk meningkatkan pemahaman berbahasa Jerman. Dalam penelitian Whittingham, Huffman, Christensen, \& McAllister (2012, p. 3), disebutkan bahwa audiobook dapat membantu pembaca berjuang untuk memahami struktur bahasa, tema dan kosakata yang sulit dari teks sastra. (Diaz \& Signes, 2014, p. 116) menambahkan ada beberapa audiobook berbasis strategi membaca yang dapat membantu mahasiswa yang memilliki kesulitan membaca tentang kosakata, dan menyusun kalimat dengan benar.

Menurut (Noland, 2011, p. 13) bahwa mendengar secara aktif dan berpikir kritis merupakan aspek yang penting dari pengalaman audiobook dan pengembangan keterampilan ini dapat membantu pemahaman secara keseluruhan. Dengan demikian, penggunaan audiobook dapat membantu mahasiswa untuk meningkatkan pemahaman dalam pembelajaran bahasa Asing. Stephens (2015, p. 254) dalam penelitiannya menambahkan bahwa praktik dari mem- 
baca ekstensif dan mendengarkan audiobook selayaknya dilengkapi dengan banyak kesempatan kepada mahasiswa untuk menggunakan bahasa secara lebih interaktif.

Berdasarkan teori-teori yang menjelaskan manfaat dan kegunaan media audiobook dalam pembelajaran beserta aspek-aspek yang terkandung dalam media audiobook, maka adapun ciri-ciri media audiobook yang baik seharusnya memiliki tiga aspek utama. Aspek pertama adalah aspek audio yang terdiri dari aspek narasi dan aspek musik. Berbicara mengenai aspek narasi, hal-hal yang perlu diperhatikan adalah volum suara, intonasi suara, ucapan dan tempo. Sedangkan aspek musik perlu memperhatikan suara tanpa adanya gangguan (noisy) dan penggunaan musik yang tepat seperti musik tema, musik transisi, musik jembatan, musik latar dan musik smash. Aspek kedua adalah mencakup komponen buku yang meliputi judul buku, petunjuk buku, kompetensi dasar, indikator, materi, tugas dan latihan, rangkuman dan tugas akhir bab. Aspek ketiga adalah aspek waktu, di mana durasi waktu yang setiap track berada pada batas maksimal antara 25-45 menit.

\section{Metode Penelitian}

Model pengembangan yang digunakan dalam penelitian ini merupakan penelitian dan pengembangan atau lebih dikenal dengan istilah $\mathrm{R} \& \mathrm{D}$ (Research and Development). Langkah-langkah penelitian dan pengembangan yang dikembangkan dalam penelitian ini diadaptasi dari pendekatan Borg \& Gall (1983, p. 775). Adapun langkah-langkah tersebut meliputi 10 tahapan berupa research and information collecting (penelitian dan pengumpulan data), planning (perencanaan), develop preliminary form of product (pengembangan desain produk), preliminary field testing (uji coba lapangan awal), main product revision (revisi produk), main field testing (ujicoba lapangan utama), operational product revision (revisi uji coba lapangan operasional), operational field testing (ujicoba lapangan), final product revision (revisi akhir produk), dan dissemination and implementation (desiminasi dan im0 $=$ plementasi).

Penelitian dilakukan pada tanggal 27 September-18 Oktober 2016 di Universitas Negeri Yogyakarta. Subjek atau responden yang diikutsertakan dalam penelitian ini adalah: 31 mahasiswa program studi bahasa Jerman semester 5 Universitas Negeri Yogyakarta. Sebagai rincian: 3 orang mahasiswa diuji coba pada uji coba tahap awal, uji coba lapangan dilaksanakan kepada 5 orang mahasiswa, dan uji coba lapangan operasional dilaksanakan kepada 23 orang mahasiswa kelas B.

Prosedur perlu dijabarkan menurut tipe penelitiannya. Bagaimana penelitian dilakukan dan data akan diperoleh, perlu diuraikan dalam bagian ini. Untuk penelitian eksperimental, jenis rancangan (experimental design) yang digunakan sebaiknya dituliskan di bagian ini.

Teknik pengumpulan data yang digunakan dalam penelitian ini adalah berupa tes seperti kuis di awal dan akhir pembelajaran di setiap pertemuan untuk mengetahui pemahaman mahasiswa terhadap materi yang dan telah dipelajari dan non test seperti wawancara, angket dan observasi untuk mengetahui kelayakan dari produk yang telah dikembangkan.

Instrumen pengumpulan data yang digunakan untuk memperkuat data tentang kelayakan produk audiobook dalam pembelajaran. Instrumen tersebut berupa angket untuk ahli media, ahli materi dan mahasiswa seperti lembar penilaian ahli media, lembar penilaian ahli materi, lembar kisikisi instrumen mahasiswa, lembar observasi keterlaksanaan proses pembelajaran, tes hasil belajar. Langkah-langkah dalam analisis data yang digunakan untuk memberikan kriteria kualitas terhadap produk yang dikembangkan adalah data kuantitatif berupa skor penilaian dari ahli media, ahli materi serta mahasiswa yang diperoleh dari kuisoner diubah menjadi data interval kemudian dikonversikan ke dalam data kualitatif dengan skala 5 menurut Widoyoko (2012, p. 262). 
Tabel 1. Konversi Data Kualitatif Angket Menjadi Data Interval

\begin{tabular}{clc}
\hline \multicolumn{2}{c}{ Data Kualitatif } & Data Interval \\
\hline SB & Sangat baik & 5 \\
B & Baik & 4 \\
C & Cukup & 3 \\
K & Kurang & 2 \\
SK & Sangat Kurang & 1 \\
\hline
\end{tabular}

\section{Hasil Penelitian dan Pembahasan}

Produk pengembangan audiobook pembelajaran mata kuliah Literatur program studi bahasa Jerman yang ditujukan untuk mahasiswa semester $\mathrm{V}$ dikembangkan dengan menggunakan aplikasi adobe audition 1,5. Produk audiobook pembelajaran Literatur diformat dalam bentuk MP3 dan kemas dalam bentuk Compact Disc (CD). Pemutaran MP3 audiobook ini dapat dilakukan pada MP3 player, laptop, HP, atau bahkan DVD. Proses produksi audiobook juga dibantu dengan penggunaan aplikasi lainnya seperti format factory yang berfungsi mengubah file audio yang diinginkan, dan audio recorder yang berfungsi untuk merekam suara. Sebagai tambahan, aplikasi Coreldraw dan Photoshop digunakan untuk mendesain kemasan produk yang telah selesai.

Tahapan-tahapan yang dilakukan dalam memproduksi audiobook Literatur adalah sebagai berikut: Pertama, mempersiapkan script atau naskah. Materi yang digunakan dalam audiobook ini berasal dari diktat Literatur program studi bahasa Jerman Universitas Negeri Yogyakarta. Sesuai dengan kriteria sebuah audiobook yang telah dijelaskan di bab 2, bahwa audiobook juga terdiri dari komponen-komponen yang dimiliki oleh sebuah buku. Komponen-komponen tersebut meliputi judul buku, kata pengantar, daftar isi, kompetensi dasar, indikator, materi, tugas latihan, rangkuman dan tugas akhir bab. Yang membedakan buku cetak dan buku audio terletak pada halaman buku. Halaman buku pada audiobook berbentuk track. Setiap halaman track berisi sub bab materi. Buku ini direkam dengan menggunakan bahasa yang lebih komunikatif dengan tujuan agar pendengar dengan mudah memahami setiap kata dan kalimat yang didengar.

Kedua, melakukan perekaman suara, proses pengeditan. Rekaman suara dilakukan oleh 3 orang Jerman (native speaker) dengan pertimbangan audiobook yang dikembangkan dapat menghasilkan kejelasan vokal, intonasi dan pengucapan. Rekaman ini dilakukan di sebuah ruangan tertutup dan kedap suara. Saat pelaksanaan rekaman, terdapat beberapa peraturan yang harus dipatuhi seperti tidak menggesek-gesekkan tangan ke celana. Ketika ingin melanjut ke halaman berikutnya, langkah yang dilakukan adalah membalikkan kertas tersebut terlebih dahulu kemudian mulai membaca. Selanjutnya, pengambilan pernafasan harus perlu diperhatikan karena dapat mempengaruhi kualitas suara yang direkam. Beberapa peraturan tersebut sebaiknya dilakukan, karena ketika suara bising direkam bersamaan suara narator maka akan menghasilkan kualitas suara yang buruk.

Ketiga, mengedit komponen-komponen utama dalam Audiobook Pembelajaran. Suara yang telah direkam, selanjutnya diedit dengan menggunakan adobe audition 1.5. Suara-suara yang tidak penting seperti kesalahan pengucapan, spasi yang terlalu panjang, suara bising terlebih dahulu dibersihkan dengan cara pemotongan suara dengan menggunakan tool scissor. Lama tidaknya proses pengeditan tergantung dengan berapa banyak kesalahan yang dilakukan saat perekaman. Selanjutnya, proses pengeditan lanjutan dilakukan dengan menggunakan mode multitrack, karena mode multitrack dapat diisi dengan berbagai elemen yang diinginkan seperti pemberian musik latar, musik smash, dan efek suara lainnya.

Keempat, pemutaran audiobook. Audiobook yang dikembangkan terdiri dari beberapa track yang mencakup judul buku, kata pengantar (Vorwort), daftar isi (Inhaltsverzeichnis), bab 1 Einführung in die Literaturtheorie, bab 2 Fabel, bab 3 Märchen, bab 4 Kurzgeschichte, bab 5 Konkrete Poesie, Kapitel 6 Lyrik dan daftar pustaka (Quellenver- 
zeichnis). Total track yang terdapat dalam audiobook adalah 53 track yang dalam artian adalah halaman pada audiobook. Rincian track tersebut adalah judul buku, kata pengantar, daftar isi dan daftar pustaka masingmasing terdiri dari satu track, bab 1 terdiri dari 15 track, bab 2 terdiri dari 7 track, bab 3 terdiri dari 6 track, bab 4 dan 5 masingmasing terdiri dari 3 track dan bab 6 terdiri dari 15 track.

Kelima, pengemasan produk awal dalam bentuk CD. Audiobook yang telah siap pakai dapat diputar pada berbagai aplikasi player yang tersedia pada laptop, handphone, MP3. Pada laptop, audiobook dalam format mp3 dapat diputar pada musik player, winamp, dsb. Pada handphone aplikasi yang disarankan adalah sonic player-Musik Buddy. Sonic player-Musik Buddy merupakan salah satu aplikasi audiobook yang memiliki beberapa kelebihan seperti bookmarks dan highlight. Sonic Player Musik Buddy terdiri dari beberapa bagian yang meliputi add track, track list, bookmarks, highlight, now playing, audio recorder. Langkah-langkah pemutaran audiobook pembelajaran Literatur adalah menambahkan track-track yang ingin didengarkan, selanjutnya track yang ingin didengar dapat dipilih pada menu track list, selanjutnya tekan tombol play untuk memutar musik.

Hasil uji coba produk dalam penelitian ini diperoleh melalui pelaksanaan uji coba awal, uji coba lapangan utama dan uji coba lapangan. Keseluruhan perangkat pengembangan produk audiobook yang digunakan dalam penelitian ini melewati beberapa tahapan validasi yang dilakukan oleh ahli media dan ahli materi sebelum diuji coba lapangan operasional. Validasi yang dilakukan oleh ahli media dan ahli materi diperlukan sebagai masukan kepada pengembang untuk mengembangkan produk pembelajaran yang layak. Media yang dikembangkan perlu divalidasi dengan tujuan untuk memperoleh saran dan komentar yang digunakan untuk menghasilkan produk pembelajaran yang layak. Pada tahap ini, langkah pertama yang dilakukan adalah menyerahkan produk berupa CD audiobook dan instrumen yang nantinya digunakan oleh para ahli untuk menguji kelayakan produk tersebut. Validasi instrumen diperlukan untuk mengetahui kebenaran aspek-aspek yang penting dan penting dari sebuah produk yang dikembangkan. Sedangkan uji kelayakan yang dilakukan oleh ahli materi dan media bertujuan untuk mengetahui kualitas produk yang dikembangkan berdasarkan teori-teori yang melandasinya.

Validasi materi pada pengembangan produk audiobook pembelajaran bahasa Jerman ini dilakukan oleh dua ahli materi yang merupakan dua dosen dari prodi bahasa Jerman Universitas Negeri Yogyakarta. Kedua validator ini dipilih sebagai ahli materi dengan alasan kedua dosen ini merupakan dosen pengampu mata kuliah Literatur di semester 5. Pada tahapan ini, kedua ahli materi menilai audiobook yang dikembangkan berdasarkan indikator-indikator yang disesuiakan dengan aspek materi dan aspek pembelajaran yang meliputi aspek desain pembelajaran, bahasa, dan evaluasi. Indikator-indikator tersebut dijadikan sebagai acuan untuk mengembangkan produk media pembelajaran yang baik dan layak.

Penilaian media audiobook pada mata kuliah Literatur dilakukan oleh dua pakar audio. Kedua pakar dipilih sebagai validator media dengan alasan bahwa keduanya merupakan pakar di bidang audio dan proses produksi audio yang tentunya diselaraskan dengan teori-teori yang mendukung. Pada tahap ini, Ahli Media menilai produk audiobook yang dikembangkan berdasarkan indikator-indikator yang disesuaikan dengan aspek audio yang dilihat dari segi narasi dan segi musik, aspek buku dan aspek waktu. Ketiga aspek ini dijadikan acuan untuk merevisi media audiobook, sehingga dapat digunakan sebagai salah media pendukung yang efektif dalam pembelajaran.

Hasil uji coba produk dalam penelitian ini diperoleh melalui pelaksanaan uji coba awal, uji coba lapangan utama dan uji coba lapangan. 


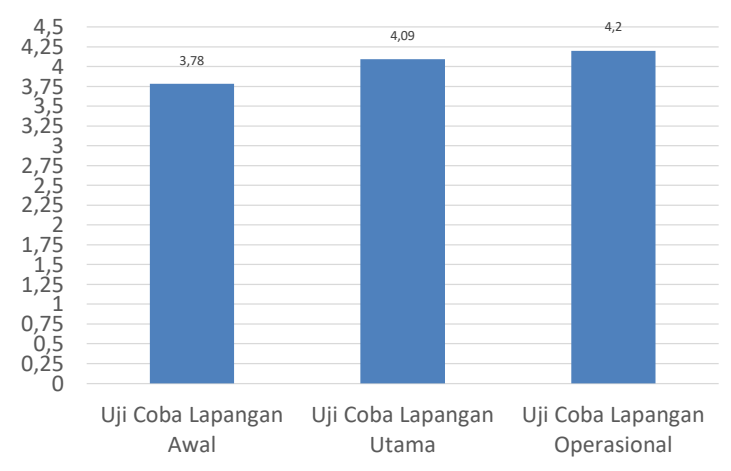

Gambar 1. Skor Uji Coba Produk

Tahap selanjutnya adalah melakukan uji coba lapangan operasional. Pada tahapan ini, uji coba dilakukan kepada seluruh mahasiswa semester 5 di kelas $B$ dengan jumlah 23 mahasiswa. Adapun tujuan dari uji coba ini adalah untuk mengetahui efektivitas produk audiobook dalam pembelajaran yang dilihat dari retensi mahasiswa dalam mengingat materi yang telah dipelajari. Untuk itu, pengujian yang dilakukan dalam uji coba lapangan operasional ini adalah melalui metode pra eksperimental design. Pra Eksperimental design ini dapat dilakukan dengan membandingkan hasil belajar dengan menggunakan metode mengajar lama dengan metode mengajar dengan berbantukan media belajar.

Peningkatan hasil belajar yang terjadi sebelum dan sesudah menggunakan audiobook, diperhitungkan dengan rumus (N-gain) yang ditentukan dengan berdasarkan rumus berikut menurut menurut Hake (Nurul, 2013, p. 99)

$$
g=\frac{S \text { post }-S \text { pre }}{\text { S maks }-\mathrm{S} \text { pre }}
$$

Mahasiswa diberi posttest untuk mengetahui keefektifan media audiobook. Dari hasil posttest diperoleh rata-rata sebesar 74,48. Berdasarkan nilai ketuntasan minimum dari mata kuliah Literatur, maka rata-rata kelas untuk hasil belajar mahasiswa adalah baik. Kategori yang ditunjukkan melalui gain skor untuk 23 mahasiswa adalah, enam mahasiswa menunjukkan pe- ningkatan hasil belajar dengan kategori "rendah", 12 mahasiswa tergolong kategori "sedang" dan lima mahasiswa lainnya tergolong kategori "tinggi".

Dari data tersebut dapat disimpulkan bahwa media audiobook efektif digunakan sebagai media bantu untuk mempermudah mahasiswa memahami wacana bahasa Jerman. Kata-kata yang didengar melalui audiobook awalnya terdengar asing, tetapi setelah audiobook didengar secara berulang-ulang hal tersebut dapat mempermudah mahasiswa untuk mengenal dan bahkan menambah perbendaharan kata. Dengan demikian, perbendaharaan kata yang banyak dapat mempengaruhi pemahaman seseorang terhadap teks wacana yang didengar maupun dibaca. Skor capaian mahasiswa dari hasil pretest dan posttest dapat dilihat dalam diagram pada Gambar 2.

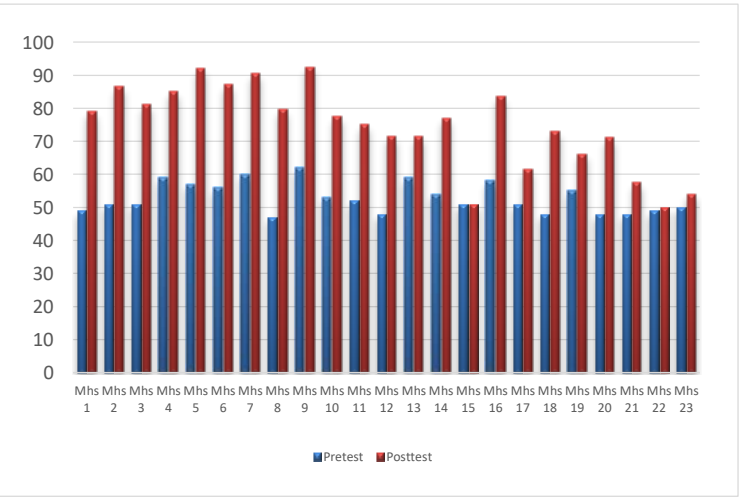

Gambar 2. Skor Capaian Mahasiswa setelah Menggunakan Media Audiobook

Media pembelajaran audiobook bahasa Jerman untuk mata kuliah Literatur dikembangkan berdasarkan studi pendahuluan berupa analisis kebutuhan. Adapun pengembangan media pembelajaran audiobook dilaksanakan melalui 10 tahapan yang meliputi tahap pengumpulan data, perencanaan, pengembangan bentuk awal produk, uji coba lapangan awal, revisi hasil uji coba lapangan awal, uji coba lapangan utama, revisi hasil uji coba lapangan, uji coba lapangan operasional, penyempurnaan produk dan desiminasi. Tujuan dari penelitian ini adalah untuk menghasilkan sebuah produk pembelajaran bahasa Jerman yang la- 
yak untuk membantu mahasiswa memahami teks bahasa Jerman baik di dalam jam pelajaran maupun di luar jam belajar.

Dalam pengembangan media audiobook pembelajaran, aplikasi utama yang digunakan adalah adobe audition CS6 sebagai program untuk mengedit suara dan memberikan tampilan suara latar yang menarik. Format factory digunakan untuk mengubah file audio sesuai dengan yang diinginkan. Audio Recorder digunakan untuk merekam narasi audio. Nero Burning digunakan untuk memasukkan file ke dalam bentuk compact disk (CD).

Media pembelajaran audiobook dikembangkan berdasarkan hasil validasi yang dilakukan oleh ahli materi dan ahli media. Selanjutnya, instrumen yang telah divalidasi, digunakan untuk menguji kelayakan produk yang dilakukan oleh dua ahli materi dan dua ahli media. Baik ahli materi maupun ahli media dipilih sesuai dengan kompetensi dan profesionalitas di bidang masing-masing. Berdasarkan hasil validasi materi, diperoleh jumlah persentase dari masing-masing aspek dengan keseluruhan aspek mencapai $87 \%$ dan tergolong kategori Sangat Baik. Sedangkan keseluruhan total penilaian dari ketiga aspek media mencapai 79\% dan tergolong Baik. Berdasarkan data tersebut dapat dikatakan bahwa media pembelajaran audiobook bahasa Jerman layak digunakan sebagai salah satu media bantu pembelajaran pada mata kuliah Literatur.

Untuk melihat efektivitas media pembelajaran audiobook yang dihasilkan dengan menggunakan strategi belajar behavioristik dapat diperoleh melalui perbandingan hasil belajar dengan kriteria ketuntasan minimal (KKM) mahasiswa. Data yang diperoleh menunjukkan bahwa 73\% mahasiswa program studi bahasa Jerman di Universitas Negeri Yogyakarta dinyatakan telah mencapai nilai KKM. Hal tersebut menunjukkan bahwa penggunaan media audiobook pembelajaran layak digunakan sebagai salah satu media pendukung (suplemen) pembelajaran bahasa Jerman.

Produk audiobook yang dikembangkan dalam pembelajaran bahasa Jerman pada mata kuliah Literatur merupakan media pendukung pembelajaran yang memiliki tujuan agar mahasiswa bahasa Jerman di tengah-tengah kesibukannya tetap belajar dan mendapatkan pengetahuan baru dari kosakata yang didengar. Melalui kosakata yang didengar secara berulang-ulang melalui media audiobook, dengan begitu hal tersebut dapat menimbulkan rasa penasaran terhadap kata-kata yang tidak dipahami. Proses inilah yang dinamakan dengan proses asimilasi.

Media audiobook pembelajaran bahasa Jerman ini memiliki kelebihan dan kekurangan. Kelebihan-kelebihan yang diberikan dari penggunaan media ini adalah: (1) penggunaan media audiobook ini efektif untuk dibawa dan diputar di mana saja. Hal tersebut dapat memudahkan mahasiswa untuk belajar di tempat yang sesuai dengan keinginan, (2) Narasi dilengkapi dengan latar musik dan effect sound yang disesuaikan, (3) Penggunaan media ini dapat digunakan dalam pembelajaran mandiri dan tatap muka, dan (4) Produk ini juga mudah diperoleh oleh mahasiswa karena tidak membutuhkan biaya. Mahasiswa dapat memperoleh file audiobook melalui via watsapp dan media sosial lainnya. Sedangkan kekurangan dari media ini terletak pada kemampuan mahasiswa dalam mendengar dan merespon pesan yang diterima melalui indera pendengaran untuk memahami pesan yang diterima.

\section{Simpulan}

Berdarsarkan hasil penelitian dan pembahasan yang telah disampaikan, maka dapat ditarik simpulan sebagi berikut. Produk yang dihasilkan berupa file audio berformat .ncc dan mp3 yang di dalamnya terdapat judul buku, kata pengantar dan pada masing-masing bab terdapat capaian belajar, indikator, materi, tugas latihan yang terkait materi yang disampaikan, dan rangkuman. Produk audiobook pembelajaran bahasa Jerman telah diuji kelayakannya berdasarkan penilaian yang dilakukan oleh ahli materi dan ahli media. Ditinjau dari hasil 
penilaian ahli materi diperoleh rata-rata sebesar 4,375 dan termasuk dalam kategori Sangat Baik, sedangkan penilaian dari ahli media diperoleh rata-rata sebesar 3,8 dan termasuk dalam kategori Baik. Kelayakan produk ini juga didukung oleh respon mahasiswa melalui uji lapangan awal, utama dan operasional. Berdasarkan hasil respon pada uji lapangan awal, produk audiobook tergolong kategori Baik. Pada uji lapangan utama dan operasional hasil respon mahasiswa menunjukkan media yang digunakan tergolong kategori Sangat Baik. Keefektifan media audiobook pembelajaran diukur melalui hasil capaian belajar mahasiswa sebelum menggunakan media dan sesudahnya. Berdasarkan perolehan data yang dilakukan dapat disimpulkan bahwa rata-rata yang diperoleh adalah 74,48 dari jumlah 23 mahasiswa program studi bahasa Jerman di semester 5 dan rata-rata ini dinyatakan telah mencapai ketuntasan minimum. Hal tersebut dapat menjelaskan keefektifan media audiobook sebagai media pendukung dalam pembelajaran.

Dari simpulan yang telah disampaikan dapat diberikan saran sebagai berikut. Produk media pembelajaran dapat digunakan sebagai media pendukung pembelajaran bagi mahasiswa di universitas yang memiliki program studi bahasa Jerman. Penelitian dan pengembangan lebih lanjut hendaknya memperhatikan kebutuhan mahasiswa dalam pembelajaran bahasa Jerman, sehingga dapat membantu mahasiswa memahami teks bahasa Jerman dengan benar dan mengubah paradigma buruk mahasiswa tentang bahasa Jerman yang sulit untuk dipelajari. Sebagai tambahan, pengembangan produk lebih lanjut ini perlu memperhatikan beberapa aspek musik untuk lebih menarik minat pendengar. Melalui pengembangan media audiobook ini diharapkan dapat digunakan setiap universitas yang ada di Indonesia yang memiliki jurusan bahasa Jerman guna kelangsungan pembelajaran yang efektif.

\section{Daftar Pustaka}

Abdulhak, I., \& Darmawan, D. (2013). Teknologi Pendidikan. Bandung: PT Remaja Rosdakarya.

Adler, B. R. (2006). Understanding human communication. New York: Oxford University Press.

Anas, A., \& Mohmammad, J. (2015). Dasardasar psikolinguistik. Jakarta: Prestasi Pustakaraya.

Bailey, K. M., \& Nunan, D. (1996). Voices from the language classroom. Australia: Cambridge University Press.

Borg, W. R., \& Gall, M. D. (1983). Educational research: An introduction (4th ed.). New York: Longman Publishing.

Budiningsih, C. A. (2012). Belajar dan pembelajaran. Jakarta: Rineka Cipta.

Degeng, I. N. S. (2013). Ilmu pembelajaran klasifikasi variabel untuk pengembangan teori dan penelitian. Bandung: Kalam Hidup.

Diaz, M., \& Signes, C. (2014). Audiobooks: improving fluency and instilling literary skills and education for development. Tejuelo, 20, 111-125.

Heshi, K. N., \& Nasrabadi, H. B. (2016). Role of logic and mentaly as the basics of Wittgenstein's Picture theory of language and extracting educational principles and methods according to this theory. Canadian Center of Science and Education, 9, 10-20.

Knowles, M. (1990). The adult learner: A neglected species. Texas: Gulf Publishing Company.

Korkmaz, Ç. (2013). Third language learning strategies pf elt learners studying either German or French. Hacettepe Üniversitesi Eğitim Fakültesi Dergisi. Journal of Education, 28, 92-104.

Noland, L. (2011). Why listening is good for all kids - especially in the digital 
age. Audiopinion, 12-16.

Nurul, T. A. (2013). Pemanfaatan visualisasi video percobaan gravity current untuk meningkatkan pemahaman konsep Fisika pada materi tekanan hidrostatis. Jurnal Inovasi Pendidikan Fisika, 02, 97-102.

Pachler, N., Evans, M., Redondo, A., \& Fisher, L. (2014). Learning to teach foreign languages in the secondary school. New York: Routledge.

Pateda, L. (2015). Tinjauan psikologis pemerolehan bahasa dan kemampuan bernalar pada anak. Jurnal Al-LISAN, 1, 44-57.

Schlücker, B. (2012). Das deutsche als kompositionsfreudige sprache. Strukturelle eigenschaften und systembezogene aspekte. Linguistik Impulse $\mathcal{E}$ Tendenzen, 46(1-25).

Seyhan, M. (2011). Internet use with learning aim: views of German Language pre-service teachers. Turkish
Online Journal of Qualitative Inquiry, 2, 52-70.

Stephens, M. (2015). Why extensive reading and listening to audio books may not be enough. The Reading Matrix: An International Online Journal, 15, 252255.

Suparman, A. (2012). Desain instruksional modern: panduan para pengajar dan inovator pendidikan. Jakarta: Penerbit Erlangga.

Whittingham, J., Huffman, S., Christensen, R., \& McAllister, T. (2012). Use of audiobooks in a school library and positive effects of struggling reader's participation in a library-sponsored audiobook club. Research Journal of the American Assosiaciation of School Librarians, 16, 1-18.

Widoyoko, E. P. (2012). Teknik penyusunan instrumen penelitian. Yogyakarta: Pustaka Pelajar. 